\title{
DO WE WANT LOPSIDED PEOPLE?
}

\section{BY Delmont K. Byan}

Society has never quite decided whether it wants well-rounded or lopsided people. Teachers and counselors, who spend much of their time helping students make the most of themselves, are among those who ponder this question.

\section{Looking for Superman}

If a well-constituted committee were to put together "The Ideal Citizen of the Future" he would be an inspired-if impossible-creature.

To start with, he probably would be "superior in intellect and health" (a committee can decree anything) with "impeccable personal integrity and social morality." Of course he would be "clean living, highly motivated, well organized and hard working." His "open mind, free spirit, and thirst for truth" would assure him no less than "a broad liberal education."

Saturated with "literature, science, and the arts" he would be "most creative and resourceful," able to "communicate effectively" and "lead well." Armed with "knowledge of the cultural heritage, social perceptiveness, and compassion for the betterment of mankind," he would set about to "improve the civilization of his time."

Through it all he would remain "honest, kind, generous, faithful, law-abiding, cheerful, and humble," even though "tempted with fame, fortune, and worldly pleasures."

Minority views of the committee might suggest that, if possible, he also be "an anti-Communist," "against the income tax," "probably a Methodist," "in favor of birth control," "a straight-thinker on foreign aid," "obviously a Democrat," "with a wholesome interest in bowling, perhaps in the Thursday League," who should "seriously consider becoming a dentist."

A completely different committee might have wanted its ideal citizen simply to "hold down a steady job, live within his means, take good care of his family, work on self-improvement, and support community progress."

The former model citizen would be a high-velocity well-rounded person. Few such people now exist. They just aren't that well rounded. Excellence generally comes in lesser amounts scattered among many individuals.

\section{Riding in All Directions}

The reality is that people are going to be lopsided, whether anybody wants it or not.

The question becomes: Should we hold to well-roundedness as an ideal for all, knowing that we will have to settle for lopsidedness anyway? Or, knowing that individuals differ, should we encourage appropriate lopsidedness all along the way? 
In schools, well roundedness would involve compulsory attendance for all, standard curricula for all, algebra for all, Cub Scouting for all, ballet lessons for all, etc. Few would go this far.

Student personnel people especially would not support this kind of well roundedness. On the contrary, they are committed to helping young people "realize their potential," "develop their interests and abilities," and express themselves vocationally." Teachers in general have been philosophically committed to this latter stand but have had difficulty accomplishing it.

While as supportive of excellence as the next person, teachers and counselors are better informed about individual differences. They have as their general goal not standardization-even in good things-but "helping all students ride off in appropriate directions." After good instruction or counseling, students should be more unlike each other than before.

This is encouraging wholesome lopsidedness. It is supporting young people as they choose their own directions of development.

\section{Choosing to Be Different}

People have only so much energy to invest. When they have divided it up among their family life, vocation, recreation, social and community activities, and spiritual being-most of them have not committed themselves evenly.

We see all around us things which work against evenness in education. In junior high school a choice must be made between French and art, or between homemaking and accelerated math. In senior high school, students cast their lot with college prep, commercial, vocational, or general curricula. And thus unroundedness begins.

A "bookworm" might be better off socially if he could play passable softball on the homeroom team. And the "social butterfly" might better have continued in Girl Scouting a while longer. But these are but examples of the right of self assertion which is championed politically and psychologically in this country.

Even talented young people, who could do many things well, find that they often must commit themselves during adolescence. If they concentrate on their social self, the intellectual or physical self may get less attention. If they choose business or sales work, their preparation is likely to take them away from carpentry or medicine. If they attend college, they are specializing away from assembly line factory work.

The recent concern for identification and education of the gifted, while promoted nationally for "manpower" rather than "self-realization" purposes, is based on the development of unusual people in special ways.

\section{On Becoming Unique}

It is apparent that work accommodates and promotes lopsidedness in people. 
Most engineers are short on liberal arts and human relations study-but somehow get along. Secluded scholars and research scientists might profit from more stimulating experiences with other people-but they are producing in their own specialties. Social service workers might profit from better understanding of the business world, and vice versa-but they are "successful" nonetheless.

\section{Establishing Priorities}

There will always be more lopsidedness than well-roundedness in people. We should, therefore, be paying more attention to the "law of the case" and seek "self attainment of the individual"-instead of trying to shape normal youngsters into all-purpose patterns.

There would be no virtue in creating a generation of nondescript dabblers. Rather we should encourage dabbling in many things and specializing in certain other things, simultaneously. Deciding which things fall in which category is the student's-and the counselor's-task.

It is reasonable to expect most people to be both craftsman and hobbyist, specialist and generalist, contributor and consumer, leader and follower, innovator and recognizer, amateur and professional.

The important thing is that young people must now-as well as throughout life-invest themselves in challenging and satisfying things of significance to them and the society they should be striving to serve. Establishing these priorities of life is the main work of becoming a mature person.

Delmont K. Bryn is Associate Professor of Education, University of Michigan, Ann Arbor, Michigan. 